\title{
\#unmaskedselfiesinsolidarity From Digital Artivism to the Collective Care of Social Art in Public Space
}

Klare Lanson, Marnie Badham, Tammy Wong Hulbert

RMIT University, Australia

klare.lanson@rmit.edu.au | marnie.badham@rmit.edu.au | tammy.hulbert@rmit.edu.au

with contributions from Ye (Sherry) Lui, Bella Capezio, and the RMIT Curatorial Collective including Wilson Yeung, Jan (Wing Ting) Sze, and Rosina Yuan.

\begin{abstract}
Contemporary mobile media affords new insights into social and creative practices while expanding our understanding of what kinds of public space matter. With the continual rise of the social in contemporary art which sees relationships as the medium, smartphones have become important devices for individual political expression, social exchange and now contemporary art. This article draws on media studies and contemporary art theories to discuss \#unmaskedselfiesinsolidarity (2020), a socially engaged artwork engaging more than 300 contributors in a few short weeks within the online and physical spaces of RMIT University in the heart of Melbourne, Australia. This artwork was instigated during the initial February 2020 outbreak of the coronavirus in Wuhan, China in response to expressions of fear and isolation, travel bans, and growing racism targeting international students. It employed one of the most pervasive barometers of popular and public culture today, the selfie. Through its messages of care alongside signs of solidarity from Chinese students suffering anxiety and isolation, \#unmaskedselfiesinsolidarity moved individual selfie expressions of identity into the realm of socially engaged arts and public space.
\end{abstract}

Keywords: selfies, COVID-19, socially engaged art, digital artivism, public space

To cite this article:

Lanson, K, Badham, M. Hulbert, T. W (2020). \#unmaskedselfiesinsolidarity. From Digital Artivism to the Collective Care of Social Art in Public Space, The Journal of Public Space, 5(4), 87-I06, DOI 10.3289I/jps.v5i4.1390

This article has been double blind peer reviewed and accepted for publication in The Journal of Public Space.

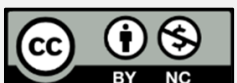

This work is licensed under a Creative Commons Attribution - Non Commercial 4.0 International License https://creativecommons.org/licenses/by-nc/4.0/ 


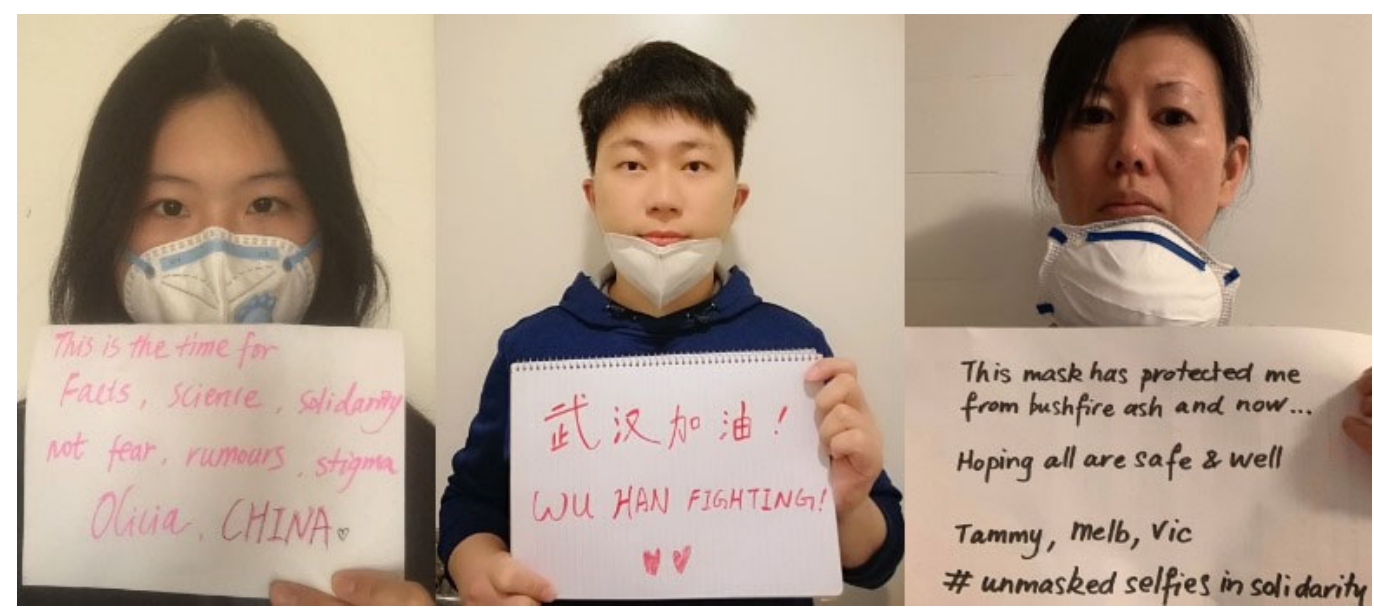

Figure I. The first images created as an invitation for \#unmaskedselfiesinsolidarity

Today is the 36th day of my quarantine, and during these days, a significant feeling I have is that the mobile phone and related online spaces seem to integrate throughout and into my everyday life. When I wake up, I pick up my smartphone to read the news and send a message to check on the safety of my family and friends. At the beginning of the quarantine, almost all of the news made me anxious. What worries me most is the issue of 'Where am I?', since the outbreak of the coronavirus. The voice of regional discrimination and racism has filled our ears. As the pandemic grows and the confirmed cases found in different areas, our society is divided into separate elements, forming fragments.

In early February 2020, Ye (Sherry) Lui and her university lecturer, Marnie Badham, sent messages back and forth, checking in on each other's well-being and exchanging information about governments' responses to the rapidly growing coronavirus crisis. Lui was enrolled to begin her research at the beginning of the academic year in Melbourne, following a visit to her family in China. While the Australian government began to initiate international travel bans, RMIT University staff returned to campus to plan for the upcoming semester. Badham and her colleague Tammy Wong Hulbert collaborated to develop a participatory art project to extend their care to international students who were self-isolating in both China and in Melbourne, unable to join their peers at university. Global pandemic conditions had further heightened political tensions between Australia and China, impacting on the Asian diaspora in Australian-increasing public fear and anxiety due to travel restrictions and social isolation. These 'new normals' not only stimulated increased stigma and racism towards people of Chinese heritage but also has seen the rise of social media platforms as a crucial digital public space for creative expression and activism.

In the creative development of the project, conversations moved from the use of masks, to the observation of racism, and the employment of social media in socially engaged art. Ideas were tested through a series of selfie images by Wong Hulbert, who chose to wear a dust mask on her face that she had recently used for smoke protection from bushfires (see Figure I). Her message of care was to be read by her social media followers: "This 
mask has protected me from bushfire ash and now... Hoping all are well and safe. Tammy, Melb, Vic". While her handwritten sign reads like the back of a postcard sending well wishes from afar, her solemn face expresses serious concern.

\#unmaskedselfiesinsolidarity was subsequently launched on social media platforms Facebook and also Weibo, a microblogging website, one of the largest social media platforms used in China. A flash flood of contributions was quickly posted online in response to the invitation for participation by students in Melbourne and across China, university staff, and their broader networks.

We are missing our international students-an important part of our community at the RMIT University, School of Art-many who are at home in China or Melbourne selfquarantined due to the coronavirus outbreak in Wuhan. Our students are feeling the emotional toll of this new global health crisis and the racism that has begun to emerge. The Australian Government has posed strict new travel restrictions on travel from China and there are more than 165,000 international students from China enrolled to start studying this semester at Australian universities.

\#unmaskedselfiesinsolidarity project introduction, Facebook Group, February 2020

This article discusses \#unmaskedselfiesinsolidarity as a socially engaged art response to the emergence of the COVID-I9 pandemic. Employing the selfie-one of the most pervasive barometers of popular and public culture on social media-this project utilises digital social media platforms as a collective public space, hosting hundreds of messages of care and signs of solidarity for Chinese students suffering anxiety and isolation (the common usage and overt repetition of the word 'we' in Figure 2 can be observed throughout the project). It speaks to the employment of contemporary mobile media to generate further understandings into critical, cultural and creative practices. With enhanced technological capacity to share content quickly and effectively, the smartphone is a highly collaborative tool for art projects that are process based, instructional, and designed to activate specific communities. More specific to \#unmaskedselfiesinsolidarity, mobile media usage can achieve collective impact that importantly highlights the immobility of international students due to public health and related border politics. This is achieved through the social connection in and around the making of mobile media art where experiences of the everyday are brought to the fore. The amalgamation of mobile media and art continues to develop our understanding of how digital public space can be understood as a fluid and iterative creative activation, with direct reference to encounters based around screen mediation. However, the "shaping condition" (Bishop, 2012) of technological connectivity is also paradoxical and artists therefore need to acknowledge ethical considerations around privacy and surveillance by the increasing corporate control of social media platforms. Take for example, the first image of Figure I, which illustrates the participants' choice to be masked rather than unmasked, using the psychology of the colour pink to highlight the need for calm thinking around scientific knowledge rather than the stigma of racism.' Sharing these often tacit forms of transmission, smartphones become creative coconspirators in this inherently political artwork, enacting the collective role of sensemaking by communicating with others through digital public spaces, and capturing how we move in and through the world. This experience provides evidence that through the lens

\footnotetext{
' For further examples, please see the project's Facebook group and Weibo page.
} 
of the selfie, the subjective self is performative, multidimensional and complex. This article proposes that the contribution of the digital materiality of the selfie within socially engaged arts practice holds key affordances within networked public space. These qualities operate specifically within social media platforms and are driven by the cultural norms of communities who utilise social media platforms. These users can be understood to enact online behaviours that move away from narcissistic endeavours, and instead amplify the action of collective listening. As socially engaged art practice, \#unmaskedselfiesinsolidarity is offered as an example of such a community, and also adds to the important archive of belonging, for the onslaught of these contemporary pandemic times (See Figure 2).

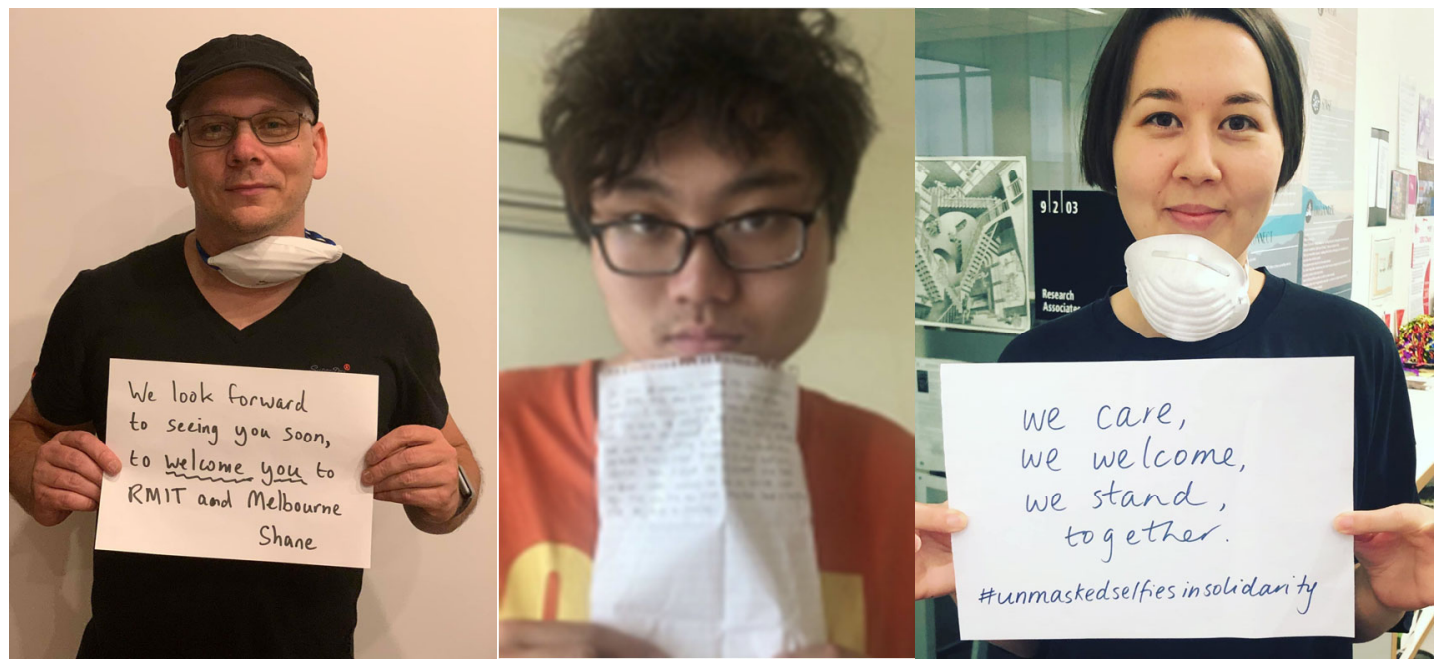

Figure 2. Signs of solidarity

\section{Mobile media and selfies as digital artivism}

Smartphones have become an intrinsic part of the creative toolkit-as a practice of methods, cultural probe, and mode of inquiry (Hjorth, 2016; Lanson, de Souza e Silva, and Hjorth, 2020). The ubiquity of mobile and social media usage inside and outside traditional art spaces has also influenced how contemporary art is received, represented and understood. It extends audiences into digitally mediated public space and enables dynamic growth of art and humanities projects related to self and identity politics. Online activity through networked digital publics have long pointed to social media engagement (van Dijck, 2013; Hjorth and Hinton, 2019), employing collective forms where "we are activated and sustained by feelings of belonging and solidarity, however fleeting or permanent those feelings may be" (Papacharissi, 20I4, p. 9). With a practise of care and inclusivity at the centre, \#unmaskedselfiesinsolidarity sought to share forms of collective mobility through the selfie, via socially engaged and public art making.

Increasingly, selfies have been adopted as a form of social and political activism, using hashtag handles for collective and affective community engagement. As a mundane millennial practice of networked self-portraiture, the selfie is socially and bodily mediated by social media platforms, networked and layered with an entanglement of multiple meanings and subjectivities. Paradoxically, they provide documentation of social and political experiences through individual context whilst also being understood as a form of 
self-portraiture which "opens up a number of unique opportunities for collaborations with others" (Palmer, 2017, p. 128). Selfies can also reinforce a more entangled approach that includes non-human agents such as, in this project, the mobile phone alongside the analogue materials of paper, pens, and the mask. Selfies, when activated through collective processes such as hashtagging, can affectively draw attention to identity politics providing visibility and access to a range of people that may be subject to inequalities based on race, gender or sexuality, as seen in recent projects such as \#blacklivesmatters and \#metoo movements. $^{2}$

There is also the poignant example of \#lamnotavirus, that also began at the onset of the racially charged phenomenon of COVID-19, instigated by the Asian diaspora around the world. This project was a form of online activism that was more generalised and geared towards opening up global dialogue around the increased acts of violence towards people of Asian descent. For \#unmaskedselfiesinsolidarity, the project was more localised, and specifically designed to show support for international students who were not only in social isolation in China and unable to travel to Australia due to travel restrictions and border closures but were also deeply affected by xenophobia from many Australian citizens (Fang, Renaldi, and Yang, 2020). As mentioned earlier, numerous selfie messages in this project underscored the more tacit forms of racism towards people of Asian descent.

Disrupting the reductive arguments of selfies being understood as networked narcissism and engendered preoccupation with the self (Marshall McLuhan 1964, cited in Wendt, 2014), Theresa Senft and Nancy Baym discuss the need to move away from a pathological approach, and diverse forms of moral panic around the consequences of selfie-making. They did this by expanding Erving Goffman's thinking around self-presentation and face work, as a form of co-presence (1959), and the need for "deep, interdisciplinary, international, multilayered understandings of selfies and all that the discourses that surround them represent" (Senft and Baym, 20I5, p. I60I; Senft, 2020). This thinking enabled a shift towards positioning the selfie as a socially mediated entity, where the entangled body (Barad, 2007) enables a complex and diverse performance of "online and offline connectivity and co-existence of images and bodies" (Warfield, Cambre, and Abidin, 20I5, p. 3, our italics). The collective approach was important for \#unmaskedselfiesinsolidarity, in particular the staging of selfie posting and the physical pasting up of contributions within the entrance foyer of Building 2 in the School of Art at RMIT University. These actions generate visuality of the Asian body as key agent and make the unspoken experiences of COVID-19 and social isolation practices amplified through networked forms of collective listening.

In The Poetics of Digital Media, Paul Frosh contemplates the role of social media tagging beyond archival purposes. The entanglement of image, names, bodies and networks exist as a highly social and embodied performance - a continuous cycle of the making of communities, where tagging is "a profoundly poetic procedure for populating and disclosing worlds ... by continually assembling multiple others in the confirmation of one's existence as a body" (2019, p. 95). The more collectively created hashtag alongside the tagging of individuals in digital imagery also assumes a stance where platform connectivity takes precedence over matters of personal privacy. This complicates our engagement with digital media—with social and highly networked collective activity comes

\footnotetext{
${ }^{2}$ See Black Lives Matter and me too. Movement
} 
responsibility and ethical thinking around why we choose to do it, how we practice the doing of data and our perceived authority to do so.

\section{Selfies, contemporary art, and digital citizenship}

Mobile media has brought about an increasing ability to augment collaborative creative practice methods specifically for artists compelled to express political concerns regarding identity, but for those who also make social and community driven work. The performativity of the smartphone selfie allows many narratives to emerge, disappear, evolve, fail and succeed; a choreography of transformation. When discussing the relational aspects of making art with community, Badham states that "through an increased focus on social engagement and participation, some new forms of contemporary arts practices blur the boundaries between the fields of public art, contemporary art, new media practice and urban design" (2013, p. 100).

There are many artists today who are now utilising photography and social media platforms as gallery, and creating the selfie to generate forms of agency, critiquing the social and cultural backlash of the isolation of self. Cindy Sherman ${ }^{3}$ uses selfies to continue her thinking on the monstrous and grotesque - queering the space of gender issues, the body, the face, and aging populations (Sehgal, 2018). Through engagement with the performative selfie in social media, artists are using networked experience as a stage to perform the reconfiguration of the social and related selfhood. Diverse examples such as feminist protest punk rock and performance art group Pussy Riot's ${ }^{4}$ well-known political activism and the parafictional Instagram performance work of Amalia Ulman (Excellences \& Perfections, 20I4), enhance our ability to logically connect social media and creative practice, thinking and performance activism to conceptually based street art projectsthrough participation, action, networked identity and the socio-political event. French urban artist and photographer JR has combined street art and documentary photography to make art public. JR draws attention to people and place, by layering large black and white photographic street paste ups on the urban canvas including warehouses, rooftops and trains. In 2008, he launched Women Are Heroes, making visible the eyes and faces of women to underline the dignity of women who are the overlooked and oppressed victims of war, poverty, and violence. Other projects like Inside Out, according to the artist's website, "is a global art project transforming messages of personal identity into works of art" (JR, Inside Out website, 2020). JR invites participants to make and upload digital portraits of people in their community. These images are made into posters and sent back to their community to be viewed locally (See Figure 3).

While artist Ai Weiwei ${ }^{5}$ is well-known for his activist employment of the selfie, a more direct precedent for \#unmaskedselfiesinsolidarity can be found within English conceptual artist Gillian Wearing's Signs that Say What You Want Them To Say and Not Signs that Say What Someone Else Wants You To Say (1992-1993). ${ }^{6}$

\footnotetext{
${ }^{3}$ See Cindy Sherman

${ }^{4}$ See Pussy Riot

${ }^{5}$ See Ai Weiwei

${ }^{6}$ See Gillian Wearing's Signs project
} 


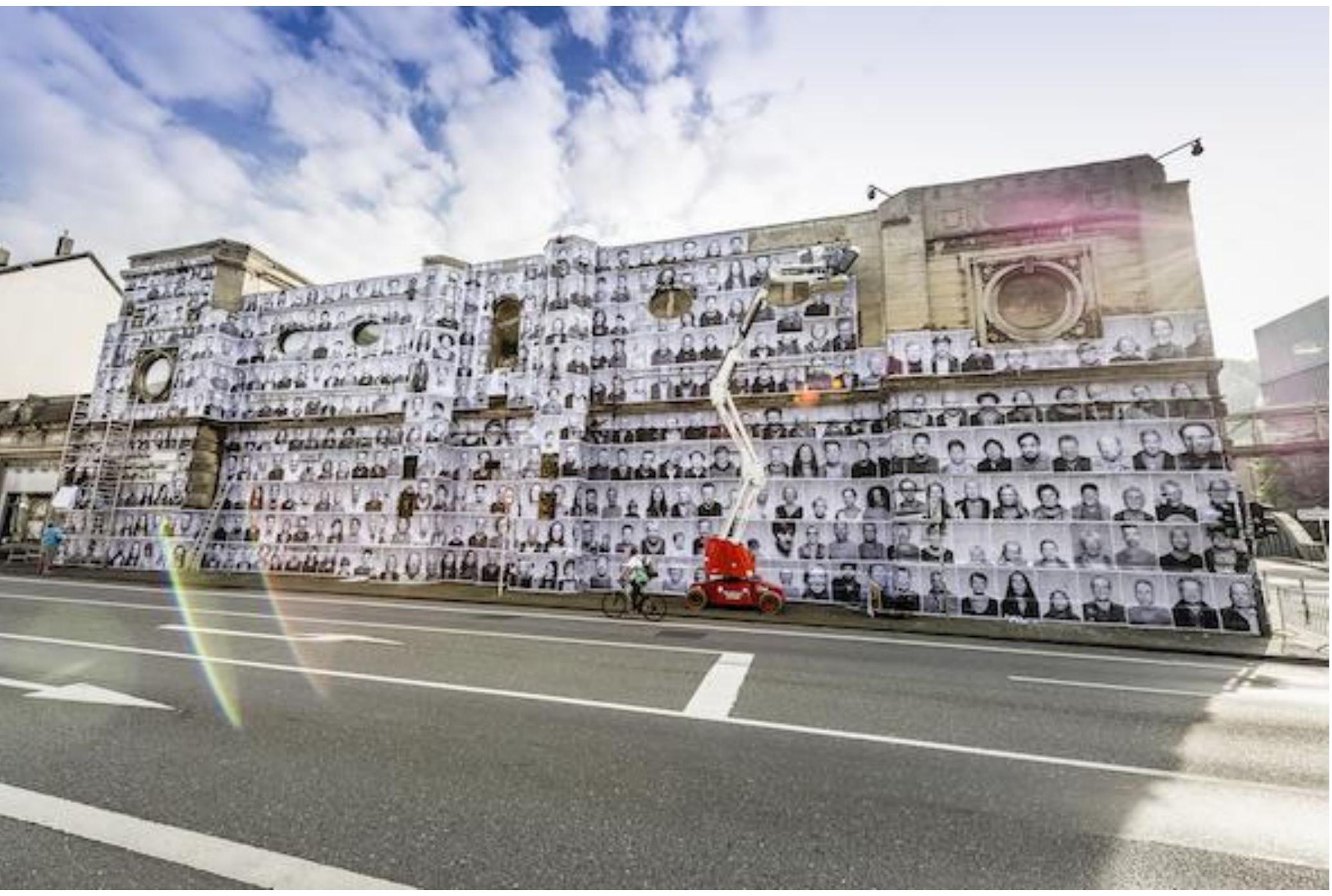

Figure 3. Inside Out Wuppertal, Germany, Daniel Schmitt (2014). Image courtesy of JR.

By interviewing and photographing hundreds of participants with handwritten signs of their innermost thoughts - encounters with strangers on the streets of LondonWearing amplifies the disconnect between public and private personas within the everyday experience. Finnish artist liu Susiraja hijacks the selfie to capture the abject humour in mundane domestic experiences. ${ }^{7}$ By objectifying her private self within this public realm, Susiraja's work engenders private forms of self-expression into a publicly heralded feminist world, serving as disruption to the cultural identity of the selfie. This creative and politicised interactivity can be seen as an extension of the avant-garde intellectual political art movement of the Situationist International in Europe.

\footnotetext{
${ }^{7}$ See liu Susiraja
} 


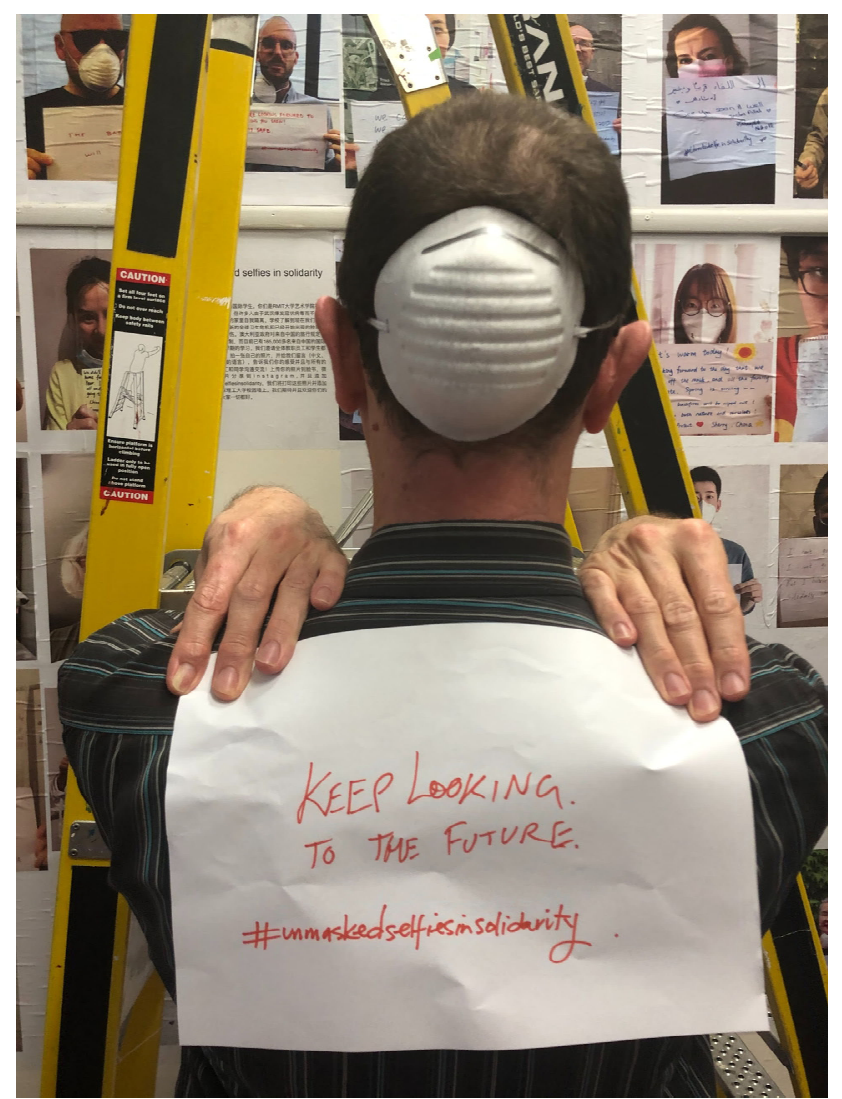

Figure 4. Future thinking for present problems

This movement in art history from the late 1950s to the early 70s began with social catalyst artist and initiator Asger Jorn, Michele Bernstein and Guy Debord focusing on social, cultural and political issues of concern (Plant, 1992). Debord's technique dérive was developed as an unplanned journey, drifting via psychogeography, a playful mapping of the psychological onto place, a subversive exploration of the social. Their technique of détournement (meaning to creatively hijack) was simply put, a misappropriation of wellknown media to create a new artwork with a different message. When working with the selfie, both dérive and détournement are interesting ways to think about mobile media artivist projects such as \#unmaskedselfiesinsolidarity. Consider Figure 4, where the participant utilised a kind of contorted, playful irony, perhaps as representative of the need for more future thinking to solve present problems and invigorate more collective thinking. Further, through performing the making of a selfie without featuring the face creates an emphatic response, one that performatively signals the need to turn our collective backs on the upsurge of overtly racist and political responses that are rife in Australia and beyond.

Through concepts of selfie citizenship, Adi Kuntsman recognises the political agency in visualising intimate forms of citizenship, ethnicity, and performative affect through the socially networked phenomenon of the selfie (2017). Kuntsman discusses innovative new ways in which activists are using mobile cultures like social media to question the politics of normalisation, ensuring different ethnicity, citizenship and ideologies are shared and therefore included within cultural conversations. As Grant Bollmer further notes: 
Selfies provide a means for a 'citizenship' that comes from placing photographs of intimate spaces and private bodies into the public spheres, reshaping who (and what) can enter into 'the political' through images that document and announce one's presence to another. Selfies, in visualizing and displaying a self, is a hailing of the unknown, networked audience, producing an encounter in the circulation of a photo, opening and remaking the possibilities of 'private' bodies to enter into public visibility (Bollmer, 2020, p. 187).

The idea of the networked audience speaks broadly to the performatives around networked society, as defined by Manuel Castells (2004). Castells introduces this idea of a society of communication technology, where "the organizational arrangements of humans in relations of production, consumption, reproduction, experience and power expressed in meaningful communication coded by culture" ( $p$. $3)$. This interconnectedness changes the framing of what it means to be a community in public space-there is a doubling effect, in that the internet "may hold as much promise for reconnecting people to communities of place as it does for liberating people from them" (Hampton, 2004, p. 217). The role of the socially driven artist moves through this network, providing more explicit commentary, reminding us of the dilemma individuals and communities face when their personal data is held by the powers of surveillance capitalism, and also perhaps opening up dialogue around future alternatives for being in the digitally mediated world.

\section{Socially engaged selfie art and collective aesthetics}

\#unmaskedselfiesinsolidarity was an invitation for creative exchange, collective forms of listening and performance in response to a particular contemporary political moment that is now archived as history of the COVID-19 pandemic through more than 300 selfie images. As an artwork created and presented in both digital and public spaces, the work can be read through the lens of socially engaged art "in a manner that resembles political and social activity, but is distinguished by its aesthetic sensibility" (Lacy, 1995, p. 19). Socially engaged art is an ideology that relates to process-based, community-oriented artmaking (Helguera, 20 I I) employing a range of artistic forms and public engagement strategies which can be described as relational, situational, or participatory. While theorists have been unable to define a particular style, form or aesthetic, like other art disciplines it is driven by particular principles and ethics (Goldbard, 2006). These forms of cultural production are typically underpinned by values of democracy through human interactions, interventions in public space, and also antagonism towards structures of power.

Socially engaged artists appear to function like ethnographers, community organisers or radical pedagogues working in responsive and open-ended ways to identify and draw attention to particular local social issues in real world situations.

\#unmaskedselfiesinsolidarity was not simply focused on communicating the expected public health messaging; rather, the motivations of organising the artist-researchers grew quickly in creative response to make visible the direct concerns of international students. Like many contemporary art theorists, curator Nato Thompson has attempted to map this expansive field citing a range of precursors such as 'relational aesthetics' (Bourriaud, 2002), 'dialogic art' (Kester, 2004) or Joseph Beuys's 'social sculpture' (Jordan, 2012). Socially engaged art also crosses over to other disciplines such as education, housing, or 
health taking art into everyday life in very visible ways. Educator Pablo Helguera suggests the resultant disciplinary ambiguity enables unexpected possibilities for social transformation to emerge (20l I).

As socially engaged artwork relies on the contributions of others (typically from outside of the artworld), this collaboration did not have a predetermined outcome in mind.

Rather, the form of 'selfie' was offered as an invitation to create and participate in a wide social network initially online and later in public space through a paste up wall on campus. \#unmaskedselfiesinsolidarity can be analysed through a range of artistic and affective frameworks; however, we pay particular attention to what Swedish curator, Maria Lind, describes as "collaborative aesthetics". She has argued a collaborative turn is enacted by artists to manoeuvre around the instrumentalising effects of both the commercial and the publicly funded art market (Lind, 2007, p. 176).

Rather than analysing or evaluating the resulting artworks, it focuses on methodologies of artistic collaboration. These kinds of collaborations can occur both between people involved, who are often, but not always, artists and between the artists and other people [...] a pronounced affinity with activism and other current ways of getting together around shared concerns, as well as a marked interest in alternative ways of producing knowledge (ibid., p. 16).

As Helguera argues, socially engaged art is a methodology not an outcome. The resulting aesthetic outcomes are typically and purposefully not individual as socially engaged artists propose a framework and methodology acting in response to a particular situation inviting individual expression within collective actions. Like socially engaged practice, mobile media has influenced art to shift away from the traditional gallery construct (Iverson and Sheller, 2016) to a more dynamic participation within an everyday sociality brought about by digital connectivity. \#unmaskedselfiesinsolidarity also embodies this collectivist approach, reinforcing that social media platforms play house to an increasing number of arts projects, and function well as digital public art space

\section{\#unmaskedselfiesinsolidarity}

\#unmaskedselfiesinsolidarity was motivated by the need to publicly show meaningful support of international students caught in the crossfire of strict new COVID-19 related travel restrictions imposed by the Australian Government, which at the time was estimated at 100,000 Chinese students enrolled in Australian Universities (Perpitch 2020, n.p.). On the first day of February 2020, the Australian Government announced a travel ban prohibiting all Chinese citizens travelling to Australia to limit the virus from spreading across 'our borders'. The Chinese nationals who arrived in Australia in advance of these restrictions were required to self-quarantine in their homes for two weeks.

At RMIT University, the concern for Chinese international students led to many staff reaching out to affected students. Reports from international students in Melbourne and abroad included the expressions of loneliness and fear, while others relayed stories of experiencing racism in public space. International students were enrolled in Australian universities as early as 1923; however, it was not until the Colombo Plan of 195I that Australia began to fund approximately one fifth of students from the Asia Pacific region (Horne, 2020). This funding strategy was originally designed to counter the influences of 
growing communist ideologies in the region. It would seem that little has changed, with continuing political disputes between Australia and China in recent months. Education was recently reported as Australia's fourth largest export at $\$ 37.6$ billion in 2018-2019 by the Australian Bureau of Statistics and universities have been estimated to lose \$3-4.6 billion in revenue from international student's fees alone in 2020 (Horne, 2020). These increasing numbers reflect China's rapidly transforming economic status over the last three decades, which has led to the mobility of a large middle class, who highly value an international university education.

The artist-researchers who instigated \#unmaskedselfiesinsolidarity invited participation through two simple actions. The first action was a call out to post a selfie alongside messages of care to the public Facebook Group created on II February 2020. Within a few days, there were over 100 selfies posted alongside messages of wellbeing, care and solidarity, which quickly grew into hundreds of individual posts. The second action was the physical paste up wall for the selfies in the busy foyer of a School of Art building, an affective haunting of the missing international students and their supporter's messages of care via the collective selfie project. Both actions generated public engagement and community conversations in online and offline public spaces, further enhancing the importance of activating relationships of care. Together, these two actions effectively extended the online digital space of the selfie to become an artistic and socio-political intervention in public space.

During \#unmaskedselfiesinsolidarity, the team discussed the use of the term 'mask' in the title of our project, as to mask or not to mask was a contentious issue in Australia.

Students from mainland China were already in the practice of wearing masks as mandated by the Chinese government, where the normalisation of mask wearing was seen as an act of protecting society and individual from the spread of viruses. In Melbourne, students wearing masks shared their feelings of being displaced and stigmatised, as many onlookers presumed the students to be unwell. To 'unmask' became a mode for revealing the true self, illuminated by the messages written by participants. The selfie collection shows a range of masked and unmasked individuals, reflecting these ongoing debates. Additionally, using masks as performative objects within \#unmaskedselfiesinsolidarity was seen as careful practice of protection for participants in relation to everyday data privacy and surveillance. Many who wished to protect themselves from facial surveillance, especially Chinese participants, chose to create a masked selfie. In light of COVID-19, it was reported that facial recognition software used in China has now further developed its Al capacity to provide a "full range of epidemic prevention information such as body temperature, mask-wearing status, and employee identity" (Li, 2020, n.p.). However, when thinking metaphorically, although many contributed selfies were indeed 'masked', the situated action of participating in our collective project could very well be seen as visible enough.

Many patterns were discovered within the choices which participants made in relation to both the messages and the selfies created. Janis Jefferies notes, "Patterns as device encourage us to think in terms of multiple perspectives and mobile subjectivities, of forging collaborations and alliances and juxtaposing different viewpoints" (Jeffries, 20I2, 125). As selfies were posted online throughout the project's duration, interesting themes were revealed. The importance of more-than-human feelings of care within the home was highlighted as many participants chose to share their selfie moment with their pet companions (See Figure 5). Animals are recognised as an important part of the home 
dynamic where "humans and their pets are entangled in various forms of intimacy and kinship, often in digitally mediated ways" (Hjorth, Richardson, and Balmford, 20I6, n.p.), it makes sense that pet relationships are a type of reciprocal care. To perform and share selfies with a pet—or even 'help' our pets create selfies—heightens well-being during periods of social isolation, and forefronts feelings of care in the message.

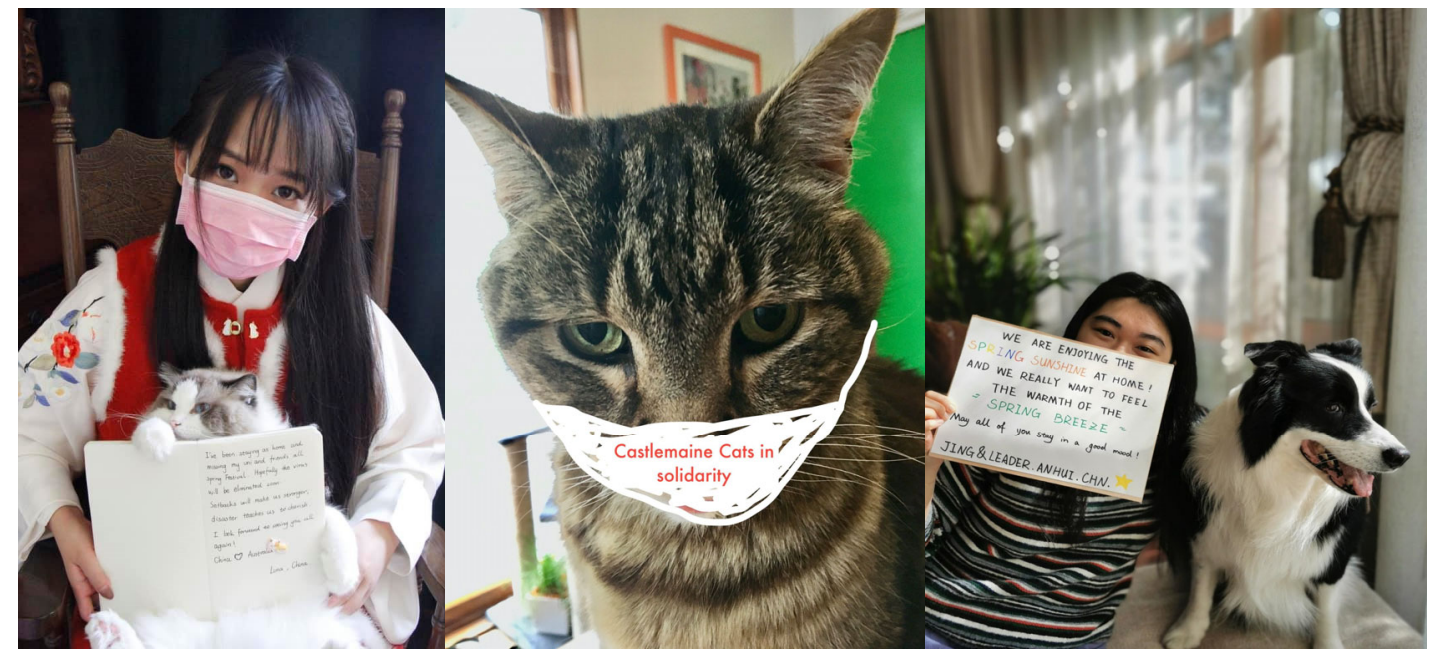

Figure 5. More-than-human acts of care

Katrin Tiidenberg understands the selfie to be a material object and draws on Science \& Technology Studies theorist Lucy Suchman's usage of the word 'configuration' to describe the ways these objects connect with cultural systems (Tiidenberg, 2018, p. 18).

Throughout Selfies: Why we love (and hate) them (ibid.), Tiidenberg argues the selfie to be a rich site for the study of collective cultural values and social norms. The selfie phenomenon is now often utilised as ironic and/or a metaphor for various types of political agency (or lack thereof) "facing new challenges of forced mobility, uneven mobility, and disrupted mobility ... and the movement of unpredictable risks" (Sheller, 2014, p. 795). This resonates with the current Australian border closures influenced by COVID-19. Understanding the various forms of mobilities involved in mobile social media practice helps to understand how the doing is performative, where "selfies gain their meanings in practices, which are context specific, situational and interactive" (Tiidenberg, 2018, p. I3I). This focus on relational aspects for \#unmaskedselfiesinsolidarity helps to create greater understandings when moving through a technologically mediated world. Yet how can a public art and social activist treatment of the selfie space help to augment these digitally mobile and networked experiences?

Like our sense of identity and place, the social atmosphere around the assembled selfie object is constantly in flux, where such an affective ambiance actively creates its subjectivity. It became difficult to utilise social media platforms primarily as a creative canvas for a project about the coronavirus without considering the ethical implications of third-party conditions, platform restrictions, and modes of surveillance and data privacy. Certainly, it has become common knowledge that affordances of social media platforms

\footnotetext{
${ }^{8}$ See Australian Government Department of Health: Coronavirus (COVID-19) advice for international travellers.
} 
"have demonstrated their important role in constructing consensus, establishing community, and mobilizing action beyond the online discursive world into the physical space of the streets" (Tierney, 2016, p. 8I). The challenge of making public art projects using online spaces is the necessity to acknowledge the privacy and surveillance contradictions within social media spaces; as noted by Jan Fernback, "Facebook is a mechanism of surveillance, but its own actions - its algorithms, its classification metrics, its distribution techniques - remain opaque" (20I2, p. 19). Cathy O'Neil warns of this opacity and the errors of misguided automated data collection that are "harvesting spoken language and images and using them to capture information" (2016, p. 154). Here the role of socially engaged artmaking via social media platforms becomes two-fold, by making heard the voices of those being discriminated against during the pandemic, there is also the potential to unveil these invasive forms of machine listening. The use of masks in the project engenders darker meaning.

\#unmaskedselfiesinsolidarity offers a more complex, playful and nuanced counter to these prejudiced perspectives by creating a public platform for individual exchange, with students and the broader community expressing themselves and respected for their independent views. They expressed the desire to be viewed as individuals beyond racial stereotypes. The project captured the early stages of this difficult period of COVID-19 by working on a local scale with the university community of students and staff while also reflecting a national crisis impacted by greater international relationships. These early personal, emotional expressions was a signal of what was to come, with entire countries making radical changes in relation to everyday movement, such as social lockdown.

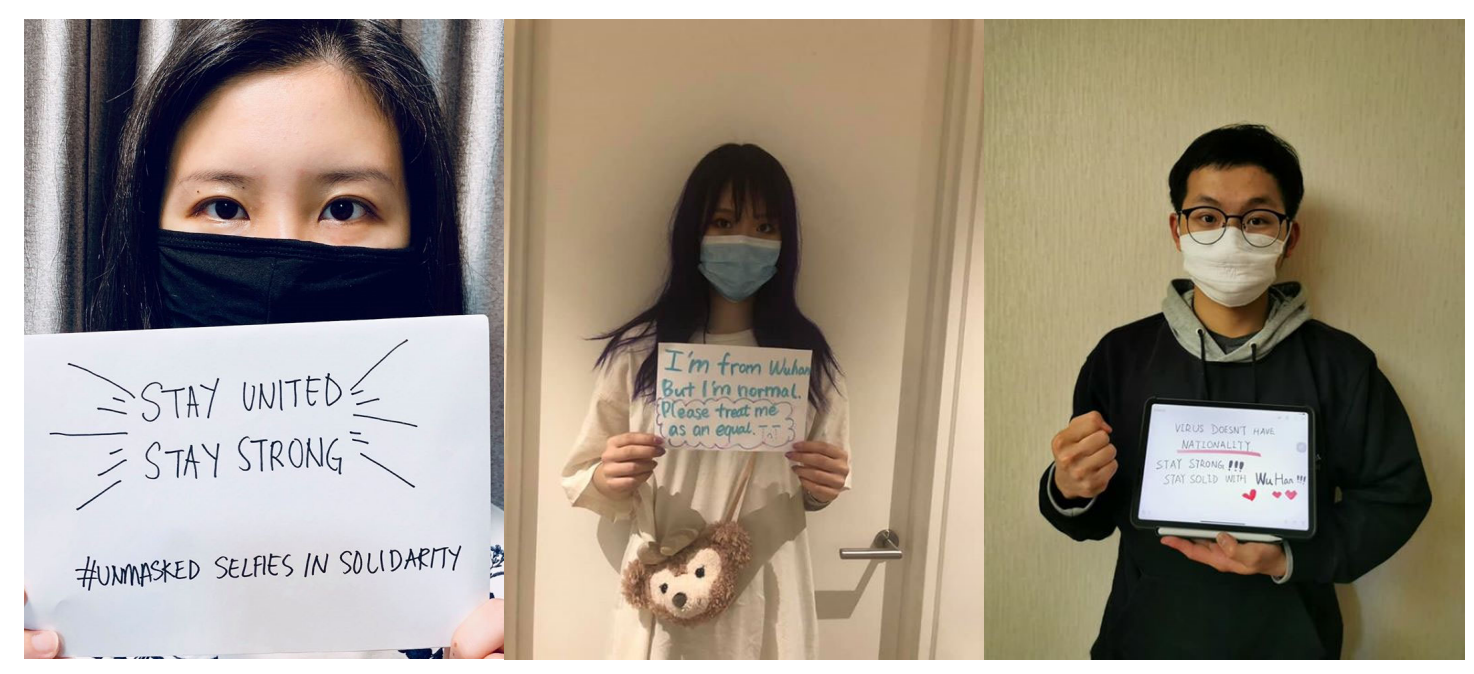

Figure 6. Messages of care from international students in China via Weibo and Facebook

\section{Forms of participation and collaboration}

From photographs and paste up walls to performative monuments, socially engaged artists employ a range of aesthetic and social methods for public participation. Ranging from the ideation of a work to the mediated and sometimes delegated labour involved in its creation and consumption, these artworks typically seek to draw attention to a particular situation or local issue and by doing so, affect participants and audiences to act on social change. Thompson explains, "Numerous genres have been deeply intertwined in 
participation, sociality, conversation, and 'the civic"' (20I2). This interconnectivity reveals a peculiar historic moment in which these notions aren't limited to art, instead they include "various cultural phenomena which have cropped up across the urban fabric" (ibid., p. 18).

In Education for Socially Engaged Art (20I I), Helguera discusses four different modes of participation in social artworks. This enables an opportunity to extend and apply this thinking to socially engaged operating within the public spaces of the digital realm.

Collaborative participation-Following initial creative development between Marnie Badham and Tammy Wong Hulbert in Melbourne, alongside Ye (Sherry) Lui participating from China, direct invitations were made to other artist-researchers working on related photo and social media activist projects. Klare Lanson is a performance poet, sound artist and writer who investigates selfies, digital artivism and collective forms of DIT (Do it Together) creative knowledge making; Isabella Capezio is an artist, photographer and lecturer with a key interest in socially aware photography (pictured in Figure 6); and Chun Wai (Wilson) Yeung (centre, Figure I) leads a curatorial collective with Jan (Wing Ting) Sze and Rosina Yuan. Members of this team share authorship for the project and are responsible for the contributions to the Facebook Group, Weibo account, translations, social engagement and installation of the paste up wall, further exhibitions of the work, and critical reflection on this iterative project. This collaborative participation depends on shared responsibility for developing the structure and content of the work.

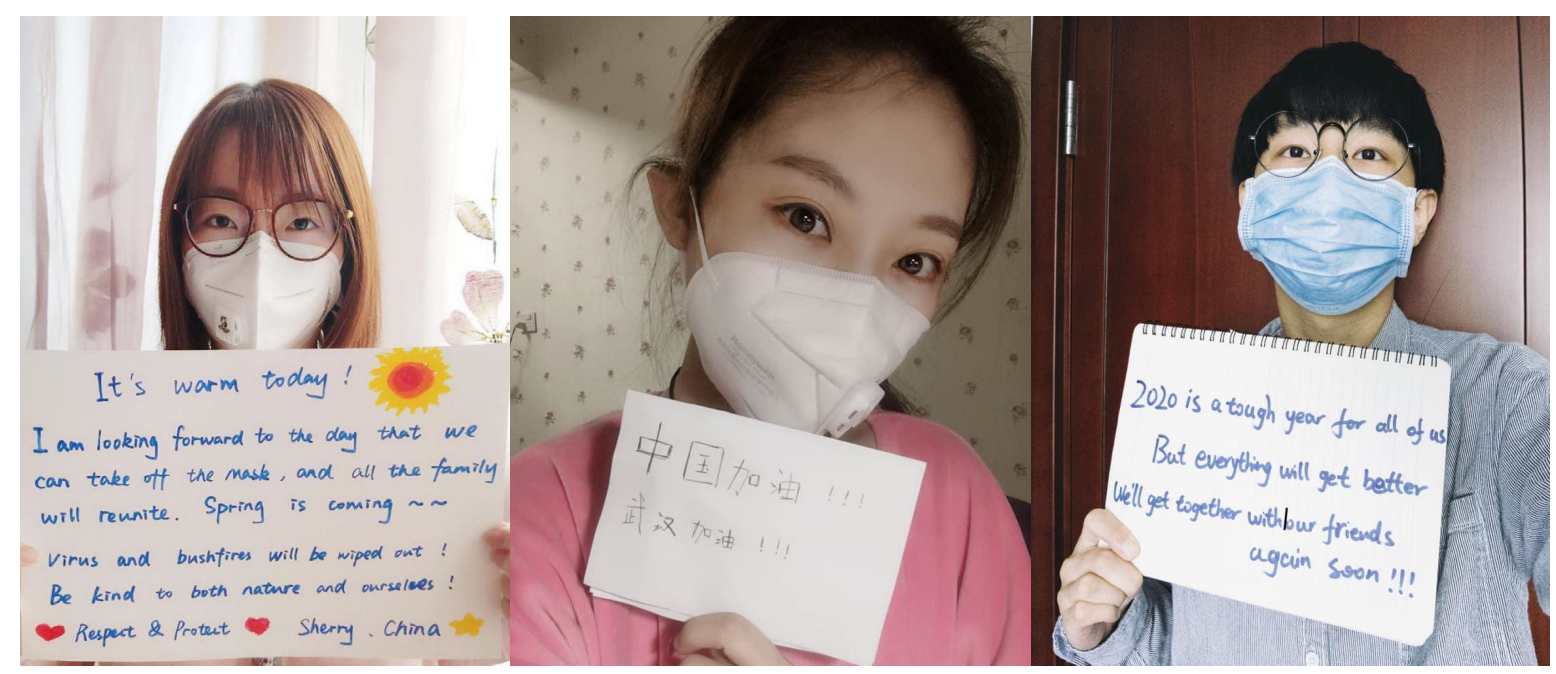

Figure 7. Early contributions from international students in China

Creative Participation - In the form of a 'Welcome Lunch' at the start of semester, an open invitation was sent to online participants to gather and show solidarity for international students both present and absent. Similar to other places around the world, news media reported that Chinatown restaurants had lost business, so a large number of dumplings were ordered, delivered and eaten together while more selfies were playfully facilitated.

Consultation with technical staff enabled the decision to use the south interior wall of the entry as a 'paste up wall'. As aforementioned, paste ups are typically associated with street 
art and more recently street activism, where wheatpaste is used to adhere prepared posters and artworks to outdoor walls in alleyways or building sites (see Figure 8).

I have always been interested in alternative modes of publication and how mediums can communicate and carry meanings. The performative aspects of projects can encourage dialogue with publics, and the physical nature of pasting something on a wall at any scale can invite participation. When small gestures become materialised and exaggerated in scale their collectiveness can speak to the need for community; both on and offline in times of dislocation and isolation. It feels important to have constant visual reminders of the struggles of others and for those who are on the margins of any society to see and hear messages of hope and solidarity.

Extract from collaborator Isabella Capezio, I March 2020
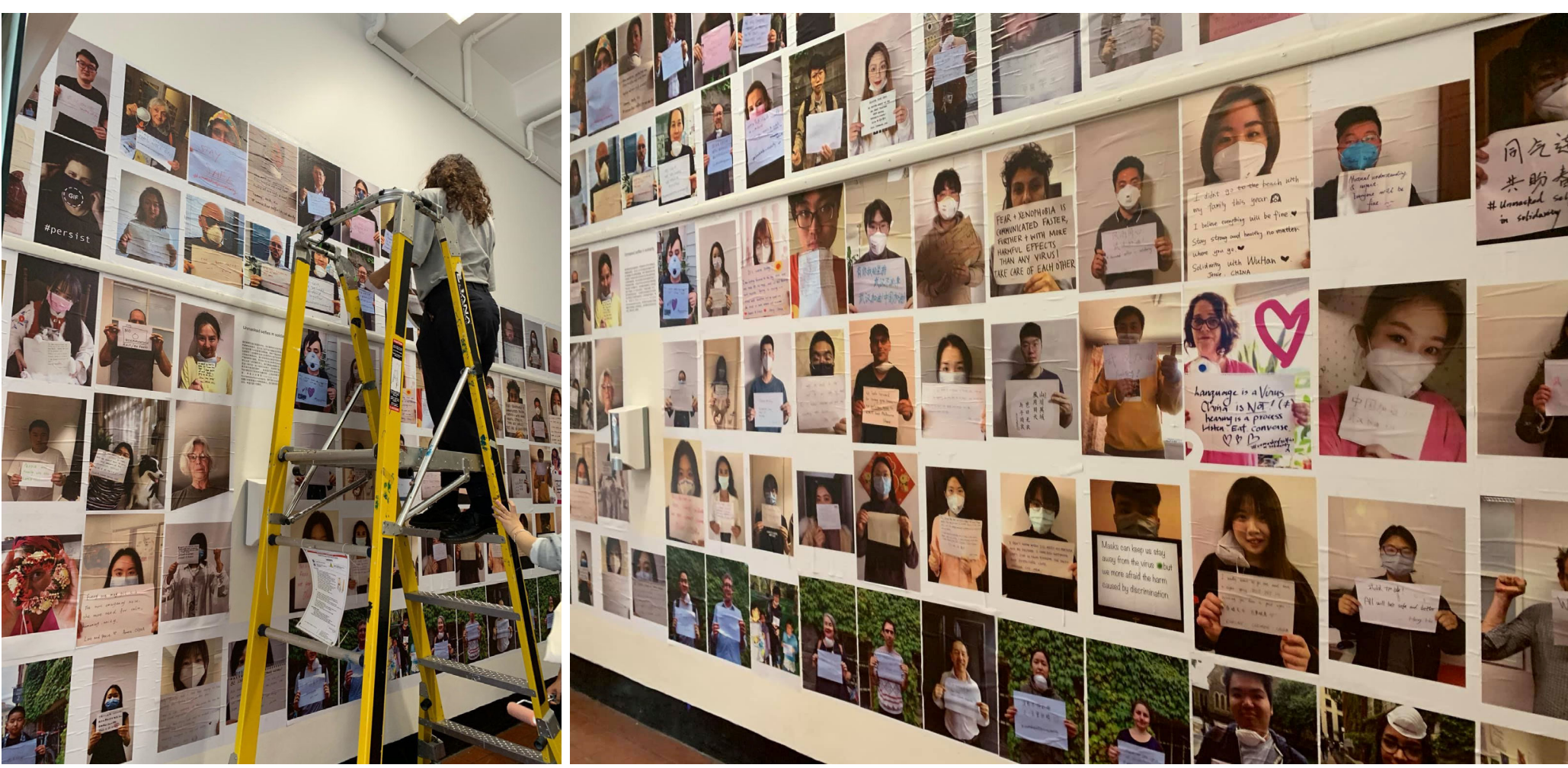

Figure 8. Paste up wall installation, School of Art, RMIT University

Directed Participation-As selfie responses from our international students grew, a wider community responded by sharing messages of care and empathy, creating an online dialogue, also accumulating into a physical wall of a fleeting but significant moment in time. A well-known example of Directed Participation in which the visitor completes a simple task to contribute to the creation of the work is Yoko Ono's 1996 Wish Tree, where participants write their thoughts on a piece of paper and tie it to a tree in the gallery. ${ }^{9}$ In the same way, both digital and public space visitors of \#unmaskedselfiesinsolidarity may also accept the invitation to contribute their own selfie to the project through very simple instructions on the project Facebook page.

\footnotetext{
${ }^{9}$ See Wish Tree
} 
\#unmaskedselfiesinsolidarity

Nominal Participation-Finally, Helguera describes Nominal Participation as a viewer's contemplation of an artwork "in a reflective manner, in passive detachment that is nonetheless a form of participation" (Huelguera, 20I I, p. I4). Here, while unable to observe the audience directly as one might in an art gallery or viewing public artworks, it can be imagined that Facebook 'friends' of participants scrolled through posts, liking and commenting on particular works. While the campus was still open, students and staff stood in the entry of Building 2 consuming the images pasted on the wall that now serves as an important archive. In this threshold space, they may step closer looking at the details of some representations and glance past others. They may imagine what message they would write and if they would wear the mask to cover their face in the photograph.

\section{Towards a digital artivism and a culture of care}

At the time of writing this article, Melbourne residents are emerging out of their second strict lockdown and there are over 46 million confirmed cases of the virus globally and over I.2 million deaths (John Hopkins University \& Medicine, 2020). These conditions halted the physical return of the local student community to Australia and although the university sector has been lobbying for concessions in the return of international students, calls to create safe pathways have been complex and delayed. The hashtag metadata of \#unmaskedselfiesinsolidarity acts in support of these political efforts, by humanising the impact Covid-19 has had on higher education's future generations, in both playful and meaningful ways. Socially engaged art projects that are small, responsive and localised underline the importance of collaborative and participatory global practice. Using public art spaces such as digitally networked communities on social media platforms also provides evidence of the iterative nature of future problem solving. Practices of care performed within everyday experience becomes key to building pathways of recovery-as we have learnt through the physical streets of Gillian Wearing's socially activated art making in the 1990s, and now through the use of social media platformativity. Interestingly, the \#freethearts activist campaign of 2015 pivoted creatively into The George Brandis Live Art Experience which framed the misappropriation of Australian federal art funding through the détourning of famous artworks, daubed and posted on social media as Brandis 'selfies', a project which rapidly transformed 'from a self-styled 'guerilla protest' to a social media campaign” (George Brandis in-art in pictures, 2015, n.p.) on Twitter and Facebook, going viral within weeks. This form of daubist artivism can also be understood as reflective of a hybridity in specific relation to the role of the digital in art history. As Claire Bishop asserts:

We are currently in a hybrid moment where non- or pre-digital materiality is sustained alongside a digital way of thinking: an approach to information in which sources are decontextualized, remixed, reorganized, and archived (2018, p. 128).

More recently the Australian arts response to government funding support decisions in relation to COVID-19 activated the \#CreateAustraliasFuture campaign, instigated by the National Association of Visual Arts (NAVA). A one-day event was activated early April, where "leading Australian creatives such as Sally Smart, Julia Zemiro and John Bell are 
speaking directly to the public and government via social media using the hashtag \#CreateAustraliasFuture" (Anatolitis, 2020, n.p.).

Accordingly, when activating Lind's 2007 concept of 'collaborative aesthetics' - which incidentally was conceived the same year as the birth of the iPhone-these contemporary social activist projects in relation to the arts industry and education are not only using mobile phones and the social media hashtagging 'instrument' to amplify an awareness of the causes they are activating, they are essentially engaging in what is becoming rapidly defined as 'digital artivism'. A blurring of art and activism within selfie making on social media platforms like Facebook, Instagram and Weibo used in \#unmaskedselfiesinsolidarity allowed for the private bodies currently in COVID-19 lockdown mode to be heard and to gain visibility around the affective atmospheres of social isolation. Known as artivismbeing the fertile merge of art and social activism which takes full advantage of our social and digital world-Tanya Toft frames it as a form of resistance, "often considered in relation to a model of conflict" (2016, p. 6I).

Artivism is motivated by a performative turn, in the sense of the ability to respond to stimulus in the world, which is causing both an actual and perceived reciprocal influence between humans and environments with new media (ibid.).

Yet forms of socially engaged art which employ selfies can also be framed as digital artivism, also including genres of memes, audio recordings, online videos including Tik Tok's latest K-pop takeover (Lorenz, Browning, and Frenkel, 2020). We have argued that mobile social media based digital artivist projects like \#unmaskedselfiesinsolidarity further strengthens social connectedness and mobilises creative practice into more socially aware public space.

Returning to the collaborative structure of the project, the RMIT Curatorial Collective (RCC), reflects on their contribution to the project as an expression of care-for self, for community and for practice.

Members of the RCC share Chinese cultural heritage and live and study in contemporary Australian society. We started to realize that many students were worried about their health and their relationship with friends and family. They have been under tremendous pressure and the outbreak has triggered 'deteriorating' criticism of the Chinese community, which is considered the origin of the epidemic and is usually regarded as people in Asian communities wearing masks in public. We explored the term 'curator' which comes from the Latin word cura and means to 'take care'. The role of a traditional curator is responsible for cultural institutions and collections; however, in \#unmaskedselfiesforsolidarity, we learned that curators not only manage artworks but also bring 'social attention' and 'community involvement' into art activities and exhibitions. The idea of 'curator-as-art activator' describes our intention to participate in the project.

Reflections from Wilson Yeung, Jan (Wing Ting) Sze, and Rosina Yuan) 21 June 2020

Despite the anxiety and fear COVID-19 pandemic has engendered, this crisis has also created a moment for reflection and the imagining of ideal futures-a return to relational social economies, a local and collective sensibility, and a timely interest in creative solutions to real-world problems. What began as an assembled online public of participatory art transformed into a collective listening network, a force driven by digital 
artivism and one that proclaims feelings of connection and solidarity whilst incidentally attempting to shine a brighter light on the darker rhythms of data surveillance. As we continue to reflect on \#unmaskedselfiesinsolidarity a few months on at the time of writing, Melbourne is only now coming to the end of its second round of lockdown restrictions, some of the strictest in the world. What previously hosted busy foot traffic where students and staff of all nationalities moved through buildings and meeting spaces, in November 2020 RMIT University is now only just starting to open its doors to teaching and research. It is hoped that soon the impromptu corridor meetings, where the physical social networks expand, where the work gets done, where conversations start, where new introductions occur, are also returned. The anticipation of this localised social engagement is heightened as the opportunity to view the project's physical paste wallcum-historical archive heralds the amplification of future possibilities. We argue that socially engaged mobile media art practice is one which operates effectively by bridging online and offline experiences as public space, activates social and aesthetic experiences of care, and drives the performative turn in contemporary art into our 'new normal' ways of being.

\section{References}

Badham, M. (2013) 'The Turn to Community: Exploring the Political and Relational in the Arts', Journal of Arts \& Communities, vol. 5, no. 2-3, pp. 93-104.

Barad, K. (2007) Meeting the universe halfway. Duke University Press, Durham, UK.

Bishop, C. (20I2) 'Digital divide'. Artforum International, vol. 5I, no. I, pp. 434-44I.

Bishop, C. (2018) 'Against Digital History', International Journal for Digital Art History, Pp. I23-I 32.

Bollmer, G. (2020) 'Selfies and Dronies as Relational Political Practices', in L Hjorth, A de Souza e Silva, \& K Lanson (eds), The Routledge Companion to Mobile Media Art, Routledge, New York, Pp. I83-192.

Bourriaud, N. (2002) [1998] Relational Aesthetics. Trans. Simon Pleasance and Fronza Woods with the participation of Mathieu Copeland, Les Presses du réel, Dijon.

Castells, M. (2004) 'Informationalism, networks, and the network society: a theoretical blueprint', in M Castells (ed.), The Network Society: A cross-cultural perspective, Edward Elgar Publishing Ltd, Cheltenham, Northampton, pp. 3-45.

Dijck, J. V. (20I3) The Culture of Connectivity: A Critical History of Social Media, Oxford University Press, New York.

Fernback, J. (2013) 'Sousveillance: Communities of Resistance to the Surveillance Environment'. Telematics and Informatics vol. 30, no. I, Pp. II-2I. 
Frosh, P. (2019) The Poetics of Digital Media. Polity, Cambridge, UK.

'George Brandis in art and pictures', 20I5, The Guardian, Fri I 9 June, viewed I June 2020.

Goffman, E. (1959) The Presentation of Self in Everyday Life. Penguin Books, New York.

Goldbard, A. (2006) New creative community: The art of cultural development. New Village Press, New York.

Hampton, K. (2004) 'Networked Sociability Online, Off-line', in M Castells, M. (ed.), The Network Society: A cross-cultural perspective, Edward Elgar Publishing Ltd, Cheltenham, Northampton, Pp. 217-232.

Helguera, P. (20II) Socially engaged art. Jorge Pinto Books, New York.

Jordan, C 2013, The evolution of social sculpture in the United States: Joseph Beuys and the work of Suzanne Lacy and Rick Lowe. Public Art Dialogue, 3 (2), I44-I67.

Hjorth, L. (2016) 'Mobile art: Rethinking intersections between art, user created content (UCC), and the quotidian', Mobile Media \& Communication vol. 4, no. 2, pp. 169-185. Hjorth, L, \& Hinton, S 2019, Understanding Social Media, 2nd edn, Sage Publications, London.

Hjorth, L, Richardson, I, \& Balmford, W. (2016) 'Careful surveillance and pet wearables: at home with animals'. The Conversation, September 5.

Horne, J. (2020) 'How Australian Universities came to rely on International Students', SI News, May 26, viewed 20 June 2020

International Education by number, Report 2020, International Education Association of Australia, February.

Jefferies, J. (2012) 'Pattern, patterning', in C Lury \& N Wakeford (eds), Inventive Methods: The Happening of the Social (CRESC). Taylor and Francis, Florence, PP. I25-I46.

John Hopkins University \& Medicine (2020) COVID- 19 'Dashboard by the Center for Systems Science and Engineering (CSSE)', viewed June 30.

JR 20I4, InsideOut, Project.

Kester, G. H. (2004) Conversation pieces: Community and communication in modern art, University of California Press, Berkeley.

Kuntsman, A. (ed.) (2017) Selfie Citizenship. Palgrave Macmillan, Cham, Switzerland.

Lacy, S. (ed.) (1995) Mapping the terrain: New genre public art, Seattle, WA: Bay Press.

Lanson, K, de Souza e Silva, A, \& Hjorth, L. (2020) 'Mobile Media Art: An Introduction', in Hjorth, L, de Souza e Silva, A, \& Lanson, K (eds), The Routledge Companion to Mobile Media Art, Routledge, New York, pp. I-8.

Li, J. (2020) 'China's facial recognition giant says it can crack masked faces during the coronavirus'. Quartz, February 18, viewed 20 March 2020.

Lind, M. (20I5) 'The collaborative turn', LOGOS, vol. 5, Pp. 88-12I. 
Lorenz, T, Browning, K, \& Frenkel, S. (2020) 'Tik Tok Teens and K-Pop Stans Say They Sank Trump Rally', New York Times, June 21, viewed 3 July 2020.

O'Neil, C. (2016) Weapons of Math Destruction: How Big Data increases inequality and threatens democracy, Penguin Random House, New York.

Palmer, D. (2017) Photography and Collaboration: From Conceptual Art to Crowdsourcing. Bloomsbury Academic, London \& New York.

Papacharissi, Z. (20I4) Affective Publics: Sentiment, Technology, and Politics, Oxford University Press, New York.

Perpitch, N. (2020) 'Coronavirus travel ban hits Australian universities, schools as Chinese students stranded overseas', ABC News, 19 Feb, viewed 10 March 2020.

Plant, S. (1992) The Most Radical Gesture: The Situationist International in a Postmodern Age, Routledge, New York.

Sehgal, P. (2018) 'The Ugly Beauty of Cindy Sherman's Instagram Selfies', The New York Times Magazine, 5 Oct, viewed 28 October 2020.

Senft, T. (2020) 'When the Face is Data', in L Hjorth, A de Souza e Silva, \& K Lanson (eds), The Routledge Companion to Mobile Media Art, Routledge, New York, pp. 174-182.

Senft, T, \& Baym, N. (20I5) 'What Does the Selfie Say? Investigating a Global Phenomenon, Introduction', International Journal of Communication vol. 9, pp. 1588-1606.

Sheller, M. (20I4) 'Mobile Art', in G Goggin \& L Hjorth (eds), The Routledge Companion to Mobile Media. Routledge, New York, pp. 197-205.

Sheller, M, \& Iverson, H. (2016) “"Editorial”. L.A. Re.Play: Mobile Network Culture in Placemaking', Leonardo Electronic Almanac, vol. 2, no. I, pp. 14-27.

Tierney, T. F. (2016) 'Reappropriating Social Media, The Public Space of Social Media: Connected Cultures of the Networked Society, 2013' in J Farman (ed.) Foundations of Mobile Media Studies: Essential Tests on the Formation of a Field. Routledge, New York, pp. 70-89.

Tiidenberg, K. (20I8) Selfies: Why we love (and hate) them (First ed.). Emerald Publishing Limited, Bingley.

Thompson, N. (ed.) (20I2) Living as form: Socially engaged art from 199I-20II. MIT Press, Cambridge, $M A$.

Toft, T. (2016) 'What Urban Media Art can Do' in S Pop, T Toft, NCalvillo, M Wright(eds), What Urban Media Can Do: Why, When, Where \& How, Stuttgart, Germany, pp. 50-65.

Ulman, A. (20I4) Excellences \& Perfections. Project.

Warfield, K, Cambre, C, \& Abidin, C 2016, 'Introduction to the Special Issue on Selfies: Me-diated Inter-faces', Social Media + Society, April-June, Pp. I-5.

Wendt, B. (2014) The Allure of the Selfie: Instagram and the New Self-portrait. Institute of Network Cultures, Amsterdam. 